\title{
What the EdTech Experience in Refugee Camps Can Teach Us in Times of School Closure. Blended Learning, Modular and Mobile Programs Are Key to Keeping Disadvantaged Learners in Education
}

\author{
Eilis Tobin ${ }^{1, *}$ and Carola Hieker ${ }^{1,2}$ \\ 1 Richmond Business School, Richmond, The American International University in London, \\ Richmond TW10 6JP, UK; c.hieker@ucl.ac.uk \\ 2 Department of Space \& Climate Physics, University College London, Dorking RH5 6NT, UK \\ * Correspondence: tobine@richmond.ac.uk
}

check for

updates

Citation: Tobin, E.; Hieker, C. What the EdTech Experience in Refugee Camps Can Teach Us in Times of School Closure. Blended Learning, Modular and Mobile Programs Are Key to Keeping Disadvantaged Learners in Education. Challenges 2021, 12, 19. https://doi.org/ 10.3390/challe12020019

Academic Editor: Carol Nash

Received: 8 June 2021

Accepted: 24 July 2021

Published: 29 July 2021

Publisher's Note: MDPI stays neutral with regard to jurisdictional claims in published maps and institutional affiliations.

Copyright: (C) 2021 by the authors Licensee MDPI, Basel, Switzerland. This article is an open access article distributed under the terms and conditions of the Creative Commons Attribution (CC BY) license (https:// creativecommons.org/licenses/by/ $4.0 /)$.
Abstract: COVID-19 is reshaping education. UNESCO estimates that at the peak in April 2020 COVID-19 disrupted the education of 1.5 billion enrolled learners in schools and universities in 190 countries. This period of unparalleled educational interruption has prompted a rapid reaction, a move to explore online distance learning solutions. Simultaneously, it has exposed the challenges and complexity of distance learning utilising Educational Technology (EdTech). Despite the many technological innovations, these challenges are not new to refugee learners, their educators and remote learning technology providers. In this article, the authors sought to explore frontline practitioners' 'lived experience' of providing education utilising EdTech when education is disrupted by forced displacement. A small scale, explorative, qualitative study was conducted with educators in refugee camps and urban settings, in Greece, Jordan, Kenya and Rwanda, prior to the pandemic. Expert interviews revealed that EdTech programmes cannot be a stand-alone solution. Blended learning programmes that are context-specific, modular, optimised for mobile technology and delivered by trained and supported teachers are the most effective. The article ends with a reflection on how these findings can be applied globally when learning is disrupted by whatever means and lead to an equitable and sustainable recovery for all.

Keywords: education; education technology; edtech; distance learning; online learning; blended learning; refugee learning; COVID-19

\section{Introduction}

As COVID-19 spreads across the globe UNESCO [1] estimates that 91\% of the world's student population will have been affected by school closures. In a staggeringly short period of time governments have had to deploy remote learning solutions and navigate the complexity of provisioning education online. For those in education, this unprecedented situation is both an opportunity and a threat.

On the one hand, the crisis offers a unique opportunity to extend the use of the adaptive, interactive learning platforms and to explore how to bring learning to the students' home and ideally meet each student's individual need. Indeed, many institutions, corporations and educators predict a paradigm shift in education, this is a time to reimagine the future of learning $[2,3]$. On the other hand, there is evidence that extended school closures will exacerbate the vulnerabilities of already marginalised learners $[4,5]$ and reduce educational achievement [6]. Experts warn closures could disproportionately hurt marginalised groups and have 'detrimental social and health consequences for children living in poverty and are likely to exacerbate existing inequalities' [7]. The UN Secretary-General, Antonio Guterres, described the situation as a 'generational catastrophe' and alongside education partners and UN agencies launched the 'Save our Future' Campaign [3]. 
As national governments turned to EdTech as an immediate response to COVID-19, in some cases providing digital devices and improved connectivity [8], it was hoped that children would continue learning by using online platforms at home [4]. Most evidently in remote areas and low-income countries this did not materialise [9,10]. COVID-19 has highlighted that for children living in poverty, school is more than a place of academic attainment. It is also a place for social and emotional learning [11,12], protection, community and provision of basic needs such as health and nutrition. In addition, children from low-income households are likely to experience digital poverty and 'a steep socioeconomic gradient' [6] to access the necessary computers, internet connectivity or supportive learning environments needed to succeed [3,13]. Children from refugee backgrounds are likely to fall into this category [9]. Moreover, they face a further challenge in that their parents often have insufficient language skills of the host country and, are lacking the technology, connectivity and computer skills to support their children [5].

The parallels of the current situation in education, notably for children living in poverty, with refugees' everyday experience of education are striking. In refugee camps and for refugees in urban settings, the absence of schools or lack of access to schools means that distance learning and the use of technology is not a temporary solution, it may often be the only solution. It was hoped that the dramatic growth in connectivity that led to an explosion in online education would overcome the insufficient funding [14], hostile host nation policies restricting refugee school access [15] and unfamiliar teaching style, curricula and language [16] experienced by refugees in accessing the global classroom.

Yet, despite being lauded as a game changer for closing the attainment gap [17] by bridging the resource gap of teachers and learning materials [18] EdTech has yet to make a significant difference to the 'Learning Poverty' [19] experienced by refugee learners. Only $1 \%$ of refugees attend university, a figure that has remained unchanged for three years [20] compared with $34 \%$ of the general population. Refugee children and youth left without an education are denied the socio-cultural and economic benefits that education provides. Deprived of their right to pursue formal, consistent education that would enable them 'cultivate the skills, knowledge and critical thinking capacities' needed to provide 'sustainable economic livelihoods ... ' [21] they face bleak futures. They are more likely to be married early, exploited, trafficked and forced into work or to take perilous journeys to Europe and elsewhere [15,22,23].

The purpose of this research, conducted prior to the pandemic, was to explore and document the attitudes and experiences of education practitioners concerning the value of EdTech in enabling refugee learners in camps and urban settings continue their education. To the extent that EdTech has been required during the pandemic, lessons will be drawn comparing the EdTech experience of refugee learners with the necessity to use EdTech to overcome the learning-imposed restrictions presented by COVID-19.

The participants of the study were all senior educators with an intimate knowledge of delivering blended learning programs predominantly in refugee settings. They were located in a non-refugee setting, in urban locations in Greece and Jordan, and in camp settings in Kenya and Rwanda. They work for NGOs, UNHCR, a major university and in education, and all provide a unique insight into the on the ground realities of implementing and delivering educational programmes using EdTech in refugee settings.

\section{Literature Review}

\subsection{Education in Forced Migration and Protracted Crises Settings}

In protracted exile and long-term encampment, entire generations miss out on education or the acquisition of particular knowledge, skills and values [24], consequently, they are denied a fundamental human right. The 1989 UN Convention on the Rights of the Child [25] affirms 'the rights of all children, regardless of status, to free and compulsory primary education, to available and accessible secondary education and to higher education on the basis of capacity'. The right to education does not diminish with forced displacement [18]. 
Beyond education as a human right, is education as an 'enabling right', a right through which other rights are realised and necessary for individuals to gain employment and lead productive, fulfilled lives. Education provides protection. Dryden-Peterson [24] asserts that it provides a sense of normality and stability. In environments that are stable and safe children are less vulnerable to exploitation, child labour, trafficking, violence, early marriage and sexual abuse [26]. Girls and young women, in particular, benefit from inclusion and greater participation in society [27]. Further, children benefit emotionally and behaviourally from education [28-30].

Education also restores hope. Dryden-Peterson [31] stresses that failing to educate refugees 'fails to make them a future' and Crae [32] argues that educational programmes develop skills that increase social capital. Accessing 'critical consciousness' skills in higher education [21] and feelings of personal empowerment [33] enables students to become change-makers in their communities. Thus, education is considered essential not just for the development of the individual, but also for the development of their communities, host countries, countries of origin and the world at large [27,28]. It also plays an important role in promoting peaceful and just communities. In post conflict situations, peace-education programmes 'show promise in changing attitudes and behaviours towards members of those perceived as other' [29] and are recognised as an important tool to help prevent terrorism and violent extremism.

\subsection{Refugees' Access to Education}

Moving from one education system to another is fraught with difficulty and refugee learners encounter several challenges. Insufficient language skills in any host country whether a country of temporary refuge or final resettlement, and, in the case of tertiary education in particular, the need for proficient English language skills, prevents access to education [34]. Unfamiliar curricula, teaching and assessment styles, and education gaps [16] make staying engaged challenging. A paper-based system of documentation means that refugees often lack the necessary documentation required in countries of asylum and past qualifications are frequently not recognised [14,21]. In addition, 'unknowable futures' $[31,35]$ and a lack of 'educational pathways' [32,36,37] make having the motivation and ability to persist with education difficult. Poverty is also a major educational barrier for refugee learners as most lack the means to cover the direct and associated costs of education. This is compounded by the need to provide for the family and a sense of 'not earning if learning' $[16,32,34]$. Refugees can also face disorientation, discrimination, exclusion, and isolation in new settings [35,37].

Education in all settings can only be realised with adequate funding. However, the scale of need in responding to sudden influxes of people fleeing can overwhelm host countries, typically poor and lacking in experience [18]. Instances of conflicts and emergencies continue to rise, yet education remains underfunded [38]. Emergencies grapple with the humanitarian-development nexus; life-saving provisions account for the majority of humanitarian aid with traditionally less than two percent of total global humanitarian aid going to education in emergencies [39].

Furthermore, a lack of opportunity for skilled work due to restrictive policies in the host country leads to a lack of incentive or motivation to pursue an education [31,40]. All contribute to an 'education deficit' for refugees [41].

\subsection{Refugees' Access to Education through Use of EdTech}

Taken at face value, EdTech has the potential to rapidly meet the challenges of providing education to millions of refugee learners. It could become a 'game changer' in improving access and quality [17,22]. Many, including Dahya [14], World Bank [17], Fincham [23], CEI [42] and Stannard and Tauson [43], have documented the potential benefits of EdTech. Their research indicate how EdTech could reach various marginalised groups of learners, enhance the educational experience and improve learning outcomes. EdTech's major impact could be in 'reach' - enabling millions of non-school-going children and youth 
to access learning materials, at relatively low cost, virtually anywhere, anytime. Additional oversight by teachers who have online training and scripted lessons could greatly expand access to education [17]. To-date, in some refugee settings with even basic infrastructure, the rapid adoption of mobile technology (handheld devices), the falling cost of tablets, and improved connectivity has enabled new and innovative ways to learn $[44,45]$. EdTech has allowed educational content to be delivered to refugees through 'connected classrooms', tablets are preloaded with content or alternatively can be connected to online learning courses, providing easy access to structured learning at low cost [46]. EdTech could also facilitate re-integration into formal schooling through faster student assessment and access to country-of-origin curricula. Reintegration could be further eased by a paperless system that documents educational attainment which can follow children and youth on the move.

Technology also mediates access to both local and global supports for refugee learners leading to improved outcomes [36]. Educational persistence is realised with academic support. Dryden-Peterson et al. [36] posit that this support could be realised using virtual contacts and access to virtual educational resources and content provided by massive open online courses (MOOCS). Additionally, virtual networks can address the issues of isolation that refugees often experience allowing learners to connect with, and participate in, education [37].

Nevertheless, EdTech has yet to deliver on its promise. The reality of delivering quality education in low resource, often extreme and unstable environments is challenging [17]. Each setting will have, in varying degrees, unique challenges. Maitland and Xu [47], Brown et al. [44] and Fincham [23] identified these as unreliable electricity supply and internet connectivity; poor technological infrastructure; a lack of computers; an over reliance on mobile data; and high costs of connectivity. These challenges are often further exacerbated by lack of wraparound support; 'computer faults, students' weak computer skills and insufficient technical support' [23].

There is also a growing realisation that EdTech is not the solution but part of the solution to educating refugees. A reliance on technology instead of trained teachers is rarely effective or successful in delivering quality education outcomes [43]. Rather, a robust pedagogy, the relationship between learning, teaching and culture, is at the heart of achieving successful outcomes. 'Education technology in and of itself does not teach students, teachers do ... ' [17]. Digital online courses tend to be most effective when the technology is complementary to a 'blended learning' approach involving 'participation in formal schooling' [18]. These courses offer additional face to face support and draw upon learner-centred pedagogies [14,18].

It is widely held that EdTech will never fully replace teachers. Teachers are critical to success in all education projects and play an important part not just in facilitating learning, but also in improving the psychosocial wellbeing of refugee learners [14,32,43]. At the same time, Stannard and Tauson [43] and the GEM Report [37] highlight that teachers must be trained and supported, otherwise 'poor teacher training leads to poor results.' Refugee learners have unique needs, including psychological, so while EdTech has the capacity to support learning, it is likely to be ineffective without a teacher-centred pedagogical approach [17,37].

Therefore, despite the transformational potential of EdTech, technology is 'no silver bullet' [17]. Dahya [14] and Stannard and Tauson [43] found that there has been too much focus on technology mainly due to the misconception that 'technology can solve all problems.' The provision of hardware, or the accessibility of educational programmes via MOOCS and other online platforms, was not sufficient to achieve quality learning outcomes [22]. There is growing acceptance that technology is simply a tool which will support and enable effective teaching and quality learning [14,22,43,48]. Further, as Fincham's 2017 research uncovered, EdTech is not always the preferred choice of refugee learners. On the contrary, online learning was the least desirable education option for Syrian refugee learners, believing that in the chaos of camp life, maintaining motivation and momentum would be difficult without personal contact with fellow students and teachers [23]. 


\section{Research Design}

\subsection{Sample}

This qualitative study explored the perspectives, or 'lived experience', of education practitioners utilising EdTech $(n=6)$. All of those interviewed are highly experienced education professionals. Five of the interviewees are currently working in education in emergencies settings and one works for a major EdTech company. Interviewees worked for various organisations including leading NGOs, International Government Aid Organisations and a Private Education provider. Interviews were conducted via Skype over a six-week period from April to May 2018.

\subsection{Measures}

In light of the literature reviewed, a six-question interview was developed to assess the perceptions and understanding of those involved in educational programmes in refugee settings, particularly the effectiveness of EdTech in the education of refugee learners. Oneto-one distance interviews were semi-structured, and respondents gave permission to record their responses which were later transcribed.

\subsection{Analysis}

Qualitative data from the interviewees was analysed through an inductive reasoning process of assigning codes to the transcribed data [49] to produce a grounded theory of staff perceptions of EdTech in refugee settings. The codes were then grouped into themes for analysis as recommended by Braun and Clarke [50]. The literature on the subject of this paper is sparse, refugee education is a nascent field and consequently light on theory however the adoption of a grounded theory approach sought to overcome this.

\section{Findings}

In Skype interviews, participants were asked about their perceptions of EdTech in refugee settings. The findings are presented around five key themes; the challenge of education for refugee learners; the importance of education programmes that reflect context; a blended learning model; the role of EdTech and finally, the future for refugees. Quotes are used throughout for illustrative purposes.

\subsection{The Challenge of Education for Refugee Learners}

Interviewees described many different challenges faced by refugee learners and acknowledged that 'students have incredibly complex lives.' Access to quality education for refugee learners is one of the biggest challenges faced. The respondents highlighted multiple difficulties, many of which concur with the research findings of, among others, Crae [32], Dryden-Peterson (various), Betts and Collier [40] and Brown et al. [44]. A lack of documentation: 'not having the right transcripts', 'transcripts having been forgotten when they left home', 'passports taken', 'they took our ID papers at the airport and haven't given them back' all of which can hinder acceptance on courses as students may need 'verification that they have attended and graduated from school'. A lack of language skills: 'language is a huge obstacle for getting into education in the national system' because 'if they are allowed to go to school in Greece, they have to learn Greek and in Turkey they have to learn Turkish'. There is the difficulty involved in moving between education systems meaning that the course content is not considered as 'culturally relevant as it could be' and is often available only in English. Although some 'had preparation programmes to get students up and running in English', there exists a notion of 'language imperialism'. Girls face particular social problems, as well as issues of security: 'little girls not allowed leave the house' or 'to go outside of the camp for education'. Often young women had to drop out of school because they become pregnant 'which is quite common'. There are the indirect costs associated with getting to school: 'transportation to school is expensive to go every day' and 'in Jordan we paid [for transportation] otherwise no one would have come'. Host nation's hostile policies can hinder access to education as frequently 'students 
can't enrol in the national system'. A lack of teachers is also cited as a challenge as 'there are a lot of programmes out there and very few educators or educational experts'. Further, a lack of access to the internet due to poor connectivity and 'did not have the internet at home'. Lastly, a lack of motivation to study: in such trying environments learners 'can't see the short-term benefit' as often they see migration as 'temporary' and as a consequence education or short-term courses are viewed as a 'waste of time' and not 'going to secure a job for me'.

There is sometimes a lack of expectation on behalf of education providers that manifests in a feeling that 'there is a lot you can't manage so I will help as much as I can', leading one interviewee to note that courses can be 'super watered down and do not hold students to the same expectation'. Interviewees expressed a feeling that courses should be universal and 'offer students something on the same standard as any student is getting'. They stressed that 'refugees are just people they're just humans' and 'no different to any other population'.

While the context is not comparable, context in all situations is important. In a nonrefugee setting there are expectations on students to have the right qualifications for the course. In non-refugee settings, particularly during the COVID-19 pandemic, students also encounter challenges such as 'students whose parents are sick and they become the main carer or children are sick' and other issues such as 'financial', 'life and illness and death' and 'anxiety or depression':

'There's nothing that I would say that I haven't seen in terms of an impact on someone's life'. Interview 6

These challenges faced by refugee learners must inform the design of any education programmes for refugees.

\subsection{The Importance of Education Programmes That Reflect Context}

A significant challenge faced by utilising online courses is the disconnect between course content and design and the lives of refugee learners (a similar problem, a lack of 'quality digital learning contents' is consistent with COVID-19 EdTech limitations [51]). The majority of programmes studied focussed on youth learners aged between 15-25. These programmes were successful only when there were a number of key components in place which were common across all programmes, some of which have been highlighted by the Stannard and Tauson report into EdTech [43] and also the UNESCO GEM Report [37]. A modular format and flexibility are '... key' 'so that makes it very easy to step out of at any point', 'they can drop in and drop out if something happens in their lives'. In addition to being able to 'see how they are progressing', this format helps 'adult learners because they can plan'. Students had to gain a specific number of modules to get the qualification, but these could be 'self-paced' and provide flexibility, 'can log on 24/7'. There is 'recognition that students might need to take a break, they might want to do it part time or might want to do it faster' and 'students can study in their own time'. Perhaps the best description of the course was a description of what it was not:

'No classes, no professors, no credit time, no due dates, students access the platform and access the projects and the projects are matched to competencies'. Interview 5

The programmes offered were 'project-based', in the case of one the projects required the completion of between 1 and 6 competencies for an associated degree (drawing similarities with the project-based learning programmes offered in disaster mitigation post COVID-19 [52]). In keeping with the findings of Maitland and Xu [47], DrydenPeterson et al. [36], Fincham [23], and reports on the penetration of mobiles phones such as in The Economist [53], the majority of refugees had mobile phones, 'most students had smart phones' and 'many study via mobile phones' so programmes were 'mobile based' and also accessible via 'laptop, desktop, iPad (tablet)...'. Though the platform through which the courses were accessed had been adapted to be more than 'repositories for material' and to allow learners to form communities, 'the AULA platform allows them to 
share posts and thoughts with other students' and with MyHelms students have access to an 'online community ... through group discussion forums ... webinars ... tutorials'. The creation of an engaging learning environment via the platform was also described: 'The online platform we are using is one of the most important aspects ... built around engagement ... engagement is everything ... ' and 'Moodle [a free and open-source learning management system] doesn't look anything like Moodle'. Evaluation of the outcomes, including issues of retention, while considered an important component were not always successfully carried out 'something we will need to look at more in future', and 'it was very difficult to find them to give me feedback, but that was the whole intention'. Further, randomised control tests (RCTs) are difficult to carry out in transient communities. In contrast, two of the courses built in 'lots' of evaluation from 'Day 1' which was viewed as vital. The provision of psychosocial support was not inbuilt to all programmes as it was not a 'core competency' or 'focus' of some. However, some of the larger programmes had 'referral pathways' available and provided 'clinical psychologists' so students could move on from the trauma of their experience. In the non-refugee setting there was a 'full time online counselling service' available. (COVID-19 has highlighted the importance of SEL, social and emotional learning, in all settings to promote academic achievement [11]). All the courses are offered in the English language. All mentioned, however, that the 'aspiration is a bi-lingual' or even a multi-lingual diploma or degree. English only courses limited access as proficiency in English was not always adequate for the courses and supplementary English classes must be offered (language was also found to be a barrier to inclusion in education during the pandemic [54]).

The importance of a partnership network in refugee education settings (also found effective for learning post COVID-19 [55]) was described by interviewees. Indeed, for one 'the model is heavily partnership dependent'. The implementation of the programmes on the ground relied on local partners to provide 'good knowledge of ... the community', 'space, technology, coaching and internship placements' and to deliver the initiatives. Partners could range from Ministries of Education to local community members each equally important in the delivering the education programme.

Regardless of whether a programme included all the above, interviewees felt it was not sufficient and that a 'blended learning' approach was needed to ensure student engagement and success of the education programme, also found to be true for learning in response to COVID-19 [56].

\subsection{A Blended Learning Model}

Interviewees highlighted the importance of a blended learning environment that includes both online and offline elements, where students could combine independent learning online alongside traditional in person, face to face, learning. This finding mirrors several of the reports in the literature review including Bergin [22] and UNESCO [18]. The majority of courses were structured around the expectation that a student would spend around $45 \%$ of their time online and around $55 \%$ in person learning. The provision of the traditional classroom setting was seen as important since:

'It is a 'very special unique learner who can jump online ... for most of us we need structure, support, goal setting, check-ins, accountability, knowing that someone cares, know that someone can help us through when things get harder or complicated'. Interview 5

The requirement of the traditional classroom setting revealed two important aspects of education, also evident with respect to the effect of COVID-19 on learning [57], that of the important role of the teacher and the important role of a learning community. Teachers are at the heart of the provision of education in refugee settings [14,43,48]. One interviewee stressed that 'we need skilled experts, educational skilled experts for education'. In the non-refugee setting practising teachers are used for the in-person portion of the course. For other interviewees, 'skilled facilitators' would suffice in the absence of trained teachers. It was also felt that there had to be recognition that teachers needed to be supported and equipped with digital skills. 
The classroom or 'teaching hub' provided a 'strong learning community, a place for them to go'. Interview 3 felt that where initially there wasn't a classroom the 'sense of community was missing . . . because if you don't have the dynamic of the classroom, it doesn't really work'. Interview 1 experienced issues of retention when access to the classroom was withdrawn for a period of time. The classroom was also a place for learners to talk to each other, to motivate each other and to network; this social aspect was considered particularly important for learners who had been out of education for a while [35].

\subsection{The Role of EdTech}

The interviewees unanimously emphasized that online education can only be part of the solution in the provision of education in any setting, as has been emphasized with respect to COVID-19 limitations [58]. As the interviewees described it, there was 'a lot of hype' around EdTech initially and it 'hasn't delivered'. Nevertheless, interviewees described EdTech as going through an evolution. In the early days there was 'a lot of focus on the technology itself rather than ... the pedagogy or the challenges or the use that you were trying to address'. Some had experience of companies donating smartphones and iPads to refugee communities in effect a 'dump them' and 'let them learn' approach. The next stage was in the explosion of educational content online though YouTube, TED, Khan Academy and the arrival of online course providers such as Coursera and MOOCs, but again the reality was this was 'overhyping of online education ... give everyone access but ... how many people stick it out?'

'If you want to get people enrolled in school and get an actual diploma or finish high school then this way can't be it, it should be universal, but not Coursera'. Interview 3

There is a recognition that technology is a 'tool' and not 'some sort of panacea' it is not going to solve the educational problem unless there are skilled educators overseeing its use. This is also echoed in the studies of [14,22,26].

'... like the very best surgical equipment it is not going to solve a problem if you don't have a skilled surgeon in the room'. Interview 5

Interviewees highlighted the importance of teachers stressing that learning was a 'social activity' that provides students with 'meaningful and engaging experiences'. EdTech could 'move students forward', 'accelerate or amplify learning' but 'only in collaboration with people and a respect for teaching' and not as a 'replacement for other sorts of educational structures'. A blended learning approach in effect.

'Any tool around EdTech are just that tools for educators to do their jobs even better'.

Interview 5

Connectivity is also a restricting factor in the adoption of EdTech solutions in developing countries and remote locations [44,47] and this was found to be additionally true with COVID-19 [59]. This coupled with the expense can rule EdTech out as an option for educators. There is also a sense of frustration with the industry that, despite the hype and the plethora of players in the field, there has been no big breakthrough. Interviewees were left disappointed post the EdTech conferences that there was nothing very different on offer.

'... get people that duplicate instead of being able to scaffold on top of others ... not enough children and youth being reached so we definitely need to do more to limit the duplication'. Interview 4

There is a need for a platform or learning management systems (LMS) that allow students to have 'a meaningful and engaging experience' that combines 'the online with the offline so it's not two separate experiences'. Platforms need to create and build a sense of community and provide content that, as Interview 6 described, 'comes alive and becomes meaningful through tech and not just a repository for content'.

However, it was also clear that despite the limitations of EdTech, the interviewees felt that there were many different positive outcomes within the current systems, which 
again echoed findings from the research of Wright and Plasterer [28], Crae and McFarland [60] and the reports by Vodafone [48] and UNESCO [18]. Through participation on the courses, refugee learners were building competencies that they might not otherwise gain. Involvement provided students with the opportunity to acquire a variety of skills such as 'time management, soft skills and life skills', 'digital literacy', 'decision making', 'critical thinking' in effect acquiring 'competencies' and 'skill sets they would need for future areas of work'.

The psychosocial aspect of involvement in education programmes was also considered a key benefit. Crae [32] too, found education to have a 'psychosocial dimension' which is also evident with respect to COVID-19 [61]. To overcome the many barriers that students encountered accessing education some programmes focused on the individual-what strengths, qualities and experience they had gained from their journey thereby 'confidence building'. Students benefitted from a sense of normality; simply by being in school or online they felt part of a 'community', 'connected to the world', and could 'communicat[e] with friends and family back home'. Some felt empowered by participation in a meaningful programme and went on to 'make change' in their lives and to have an impact in their communities. Participants also gained qualifications ranging from Certificate of Participation to a Bachelors' Degree again equipping them for their future lives.

\subsection{The Future for Refugees}

For the majority of the interviewees, the experience of delivering education programmes in refugee camps or in urban settings gave them a unique perspective on the lives and futures of refugee learners. For some, there is a feeling that the 'world has failed to respond to the mass migration of people' and that despite the many initiatives there is still a fairly limited reach and that there just isn't sufficient money or capacity to reach the current numbers. This is echoed by Miliband [30] and Betts and Collier [40] in their respective books.

This impasse has been reached because of 'polarised opinions of what to do' and that without significant changes in policies little will change (similar views hold related to COVID-19 [62,63]).

'This is way beyond education, it's about politics, it's about money, it's about governments so if those things aren't working harmoniously, I am not sure there can be any broad scale positive impact unfortunately'. Interview 5

For one, there is a feeling that NGOs may even be part of the problem by 'maintaining them [refugee learners] in the situation'. Even if the underlying intentions are good, they are in effect 'warehousing refugees' as Smith described refugee camps in 2004 [64].

Despite this assessment, for most, there are reasons for hope and cautious optimism. There is hope around the fact that organisations are finding ways to work 'across borders' and are exploring new initiatives which recognise that education may be the solution for these marginalised populations. Such hope is also evident with respect to COVID19 [65]. There is a sense that increased access to education facilitates cultural understanding, solutions which involve 'integrated education responses are some of the best ones' ensuring both communities benefit; 'I see a huge difference in Greece ... I think we are getting places.'

\section{Limitations}

There are limitations to this study. The research was conducted prior to the pandemic; however, the findings remain relevant and insightful into the use of EdTech for marginalised learners anywhere during and post COVID-19. The limited number of interviewees and the lack of random selection was a function of the difficulty of identifying and contacting highly experienced people working in this field. In addition, the qualitative nature of the data means results cannot be generalised but rather can be relatable. Finally, one of the interviewees is not based in the field of provision of education to refugees. However, as it 
is a leading online educational provider, it was hoped to uncover best practice for online learning in general which could be applied to the refugee situation.

\section{Conclusions}

More than 3.7 million refugee children and youth are not in school. Due to the current pandemic this number has risen even further. Daily, they encounter enormous challenges that are both context-specific and political in accessing quality education. EdTech was lauded as a 'silver-bullet' in the education of refugees; its ubiquity, adaptability and potential low cost should have meant that many of the barriers' refugees faced in accessing education were overcome. To-date, EdTech has not delivered-the numbers of refugee children out of school remain stubbornly high in comparison to those in stable environments. The limited research that has been conducted has focused mainly on sitespecific use of technology by refugee learners. In this study we have aimed to broaden that focus by interviewing those who deliver education using EdTech in different refugee settings to gain their first-hand experience. These findings conclude, and concur with the limited existing research, that effective education programmes in refugee settings cannot be delivered by EdTech alone; rather they should be context-specific, modular and mobile, blended learning programmes. These results, on the limitations of EdTech, are found equally relevant to COVID-19 responses in education.

\subsection{Implications for Marginalised Learners during School Closures Globally}

Given the current crisis in education and the similarities with refugee remote learning, the authors, who mentor Syrian refugees, questioned whether the research findings could be reconceptualised and applied to the current challenge of educational disruption for the most at-risk students due to the COVID-19 pandemic.

With global school closures keeping at the peak more than 1.5 billion children and young adults out of school it is hoped that education can continue through the use of EdTech via the internet on laptops, tablets and mobiles. This sudden shutdown of schools, the cancellation of all face-to-face lessons, the rapid shift online and the adjustment to a new pedagogy due to COVID-19 shares many similarities to emergency remote teaching which refugee learners experience. Emergencies exaggerate existing disadvantages; the conclusions and findings of the original research into the use of EdTech in emergencies could help inform the implementation of online learning in any country for marginalised learners. The main similarities are presented here.

The authors recognised parallels between refugee learners and COVID-19 disadvantaged learners and a pattern of events in maintaining education continuity whether education is shut down by forced displacement or pandemic:

1. Disruption: a shock that overwhelms and shuts down the education system

2. Reaction: learning moves online utilising EdTech

3. Complication: the move online is complex and multi-dimensional for disadvantaged learners everywhere and can lead to notional inclusion but practical exclusion

- Disadvantaged learners, refugee learners and their parents frequently have insufficient language proficiency and skills to navigate an online solution at home.

- Many disadvantaged households need additional supports. Many may not have access to computers or connectivity to access the online resources. Some may not provide a suitable place to learn.

- Lack of appropriate technical support can lead to disillusion and ultimately dis-engagement with learning.

- Unfamiliarity with the pedagogy of teaching online can alienate learners.

- Many disadvantaged households need psychosocial supports in addition to educational supports.

4. Rehabilitation: attempts are made to plug the resource gap of facilities, teachers, equipment and materials and reduce the attainment gaps 
5. Co-operation: learnings from international communities are shared and the aim is that 'no one is left behind' due to unequal access to education

Findings from the original research show that EdTech programmes should start with the disadvantaged learner, and not the technology. Programmes must adopt a childcantered approach and be relevant to learners' lives. Hardware dumps are not sufficient for disadvantaged groups in the hope they may be able to self-learn. Effective online learning results from creative design and planning that considers modality, fully online or blended; communication synchrony, synchronous or asynchronous or a hybrid model that blends both and facilitates flexible learning; the role of the teacher and of the student for both engagement and feedback and the pedagogy.

Overall, it was found that programmes that utilised a blended learning approach combining traditional face-to-face learning, virtual instruction and online resources available through an engaging Learning Management System (LMS) are key for the success of online learning. Completing online learning requires personal skills including independent learning, motivation, persistence and academic skills such as report writing and digital literacy, which refugee and disadvantaged learners rarely combine. The presence of trained, supported and motivated teachers is essential to encourage students to remain in education and ultimately produce better learning outcomes. To meet this need in a situation where it is not possible to bring student and teacher together in one location, Dahya et al. [14] suggest that this support could be realised by virtual support networks providing 1:1 or small group tutoring.

Also, programmes that are modular, accessible $24 / 7$, anywhere, allowed students to complete programmes over time without the restriction of a traditional school timetable. The ubiquity of mobile phones can enable all learners access online programmes, connect with their teachers and with one another.

To achieve these goals, it is key that stakeholders collaborate. Effective collaboration could yield more and new ideas rather than duplication in this area. The educational experts interviewed in this study called for developers to collaborate with educators to provide platforms or learning management systems (LMS) that engage learners and enhance teaching by enriching the learning experience. LMS need to be digital repositories for lecture slides, audio, grades and other administrative tasks of education as well as a platform where students, communities, content and technology can intersect. They should provide a high level of accessibility and functionality without overwhelming the user and allow collaboration with other users whether students, teachers or parents. These improvements would impact on the persistence of students as experienced in the nonrefugee setting, which have an exceptional retention rate. Partners in the private sector were also considered to be a vital part of the ecosystem required to deliver blended learning programmes in complex settings. Business could take on an increasingly important role in provision of education solutions, including partnerships that work to improve connectivity and bring down the costs of Wi-Fi and partnerships to provide hardware and cover the associated costs of education.

Globally, education is experiencing unparalleled disruption. All have been affected but not equally affected. This is a moment to turn the crisis into an opportunity. Innovative education technology solutions could address access, connectivity and technical challenges and deliver context-appropriate, engaging content remotely to learners while simultaneously supporting teachers and parents. The global shift to online learning could herald the long-awaited era that 'leave[s]-no-one-behind' through continuity, inclusion and equity in education.

\subsection{Recommendations for Future Research}

The widening of the attainment gap among children and young adults already on different achievement trajectories is a significant concern after any disaster that closes schools. Further research at this time with teachers, learners and parents could assess the effectiveness and impact of using EdTech to teach vulnerable children remotely. The 
collection of data and evidence could demonstrate the value, or not, of the use of technology to support learning continuity and effectiveness of the most marginalised children affected by COVID-19.

Author Contributions: E.T. designed the study, collected the data, supervised data analysis and wrote the preliminary draft of the manuscript. E.T. and C.H. wrote, reviewed and edited subsequent drafts. All authors have read and agreed to the published version of the manuscript.

Funding: This research received no external funding.

Institutional Review Board Statement: The study was conducted according to the ethical guidelines of the Department of Management, Birkbeck University, London.

Informed Consent Statement: Informed consent was obtained from all subjects involved in the study.

Data Availability Statement: The data that support the findings of this study are available on request from the corresponding author. The data are not publicly available due to privacy restrictions.

Acknowledgments: The authors would like to thank the interviewees for their assistance and participation in this study.

Conflicts of Interest: The authors declare no conflict of interest.

\section{References}

1. UNESCO. Supporting Learning Recovery One Year into COVID-19: The Global Coalition in Action. 2021. Available online: https:/ / unesdoc.unesco.org/ark:/48223/pf0000376061 (accessed on 16 July 2021).

2. Fullan, M.; Quinn, J.; Drummy, M.; Gardner, M.; Education Reimagined; The Future of Learning. A Collaborative Position Paper between New Pedagogies for Deep Learning and Microsoft Education. 2020. Available online: http://aka.ms/ HybridLearningPaper (accessed on 16 July 2021).

3. UN. Policy Brief: Education during Covid-19 and Beyond. 2020. Available online: https://www.un.org/sites/un2.un.org/files/ sg_policy_brief_covid-19_and_education_august_2020.pdf (accessed on 16 July 2021).

4. UNICEF. Promising Practices for Equitable Remote Learning. Emerging Lessons from COVID-19 Education Responses in 127 Countries. 2020. Available online: https:/ / www.unicef-irc.org/publications/pdf/IRB\%202020-10.pdf (accessed on 16 July 2021).

5. You, D.; Lindt, N.; Allen, R.; Hansen, C.; Beise, J.; Blume, S. Migrant and displaced children in the age of COVID-19: How the pandemic is impacting them and what can we do to help. Migr. Policy Pract. 2020, 10, 32-39.

6. Eyles, A.; Gibbons, S.; Montebruno, P. Covid-19 School Shutdowns: What Will They Do to Our Children's Education? CEP Covid-19 Briefings Cepcovid-19-001; Centre for Economic Performance, LSE: London, UK, 2020.

7. Van Lancker, W.; Parolin, Z. COVID-19, school closures and child poverty: A social crisis in the making. Lancet Public Health 2020, 5, e243-e244. [CrossRef]

8. Berten, J.; Besche-Truthe, F.; Boyashov, A.; Crockett, C.; Cufré, S.; Igbojekwe, E.; Kaasch, A.; Laws, M.; Schulze Waltrup, R.; Shriwise, A. An equitable and sustainable recovery from COVID-19? Glob. Soc. Policy 2021, 21, 153-182. Available online: https://journals.sagepub.com/doi/pdf/10.1177/1468018121996078 (accessed on 16 July 2021).

9. Haßler, B.; Nicolai, S.; McBurnie, C.; Jordan, K.; Wilson, S.; Kreimeia, A. EdTech and COVID-19 Response [EdTech Hub Report] (Working Paper No.11); EdTech Hub: London, UK, 2020. [CrossRef]

10. Hajjar, M.S.; Abu-Sittah, G.S. The multidimensional burden of COVID-19 on Syrian refugees in Lebanon. J. Glob. Health 2021, 11, 05003. [CrossRef] [PubMed]

11. Bulat, J.; Norman, J.; Randolph, E.; Promoting Social and Emotional Learning During School Closures: Why and How. RTI International. 2020. Available online: https://shared.rti.org/content/promoting-social-and-emotional-learning-during-schoolclosures-why-and-how (accessed on 16 July 2021).

12. UNESCO. 1.37 Billion Students Now Home as COVID-19 School Closures Expand, Ministers Scale Up Multimedia Approaches to Ensure Learning Continuity. 2020. Available online: https:/ / en.unesco.org/news/137-billion-students-now-home-covid-19 -school-closures-expand-ministers-scale-multimedia (accessed on 16 July 2021).

13. David, R.; Pellini, A.; Jordan, K.; Philips, T. Education during the COVID-19 Crisis: Opportunities and Constraints of Using EdTech in Low-Income Countries; EdTech Hub \& Digital Pathways at Blavatnik School of Government: Oxford, UK, 2020; Available online: https:/ / www.bsg.ox.ac.uk/sites/default/files/2020-04/Education-during-covid-19-crisis.pdf (accessed on 16 July 2021).

14. Dahya, N. Education in Conflict and Crisis: How Can Technology Make a Difference? A Landscape Review; GIZ, USAID, WVI: Bonn, Germany, 2016; Available online: https:/ /inee.org/resources/landscape-review-education-conflict-and-crisis-how-cantechnology-make-difference (accessed on 16 July 2021).

15. Nicolai, S.; Hine, S.; Wales, J. Education in Emergencies and Protracted Crisis; ODI: London, UK, 2015; Available online: https: // odi.org/en/publications/education-in-emergencies-and-protracted-crises-toward-a-strengthened-response/ (accessed on 16 July 2021). 
16. Dippo, D.; Orgocka, A.; Giles, W. Feasibility Study Report: Reaching Higher: The Provision of Higher Education for Long-Term Refugees in the Dadaab Camps, Kenya; The Borderless Higher Education for Refugees Partnership; York University: Toronto, ON, Canada, 2012; Available online: http://bher.eecs.yorku.ca/wp-content/uploads/2018/09/BHER_Feasibility_Study_Report_February_ 20_2013_v4_new_org_chart_9-3-13.pdf (accessed on 16 July 2021).

17. World Bank. ICT and the Education of Refugees. 2016. Available online: http://documents.worldbank.org/curated/en/455391 472116348902/pdf/107997-WP-P160311-PUBLIC-ICT-and-the-Education-of-Refugees-final.pdf (accessed on 16 July 2021).

18. UNESCO. A Lifeline to Learning: Leveraging Technology to Support Education for Refugees. 2018. Available online: https: / / unesdoc.unesco.org/ark:/48223/pf0000261278 (accessed on 16 July 2021).

19. World Bank. Ending Learning Poverty: What Will It Take? 2019. Available online: https://openknowledge.worldbank.org/ handle/10986/32553 (accessed on 16 July 2021).

20. UNHCR. Turn the Tide. Refugee Education in Crisis. 2017. Available online: https://www.unhcr.org/turnthetide/ (accessed on 16 July 2021).

21. Dryden-Peterson, S.; Giles, W. Higher education for refugees. Refuge 2010, 27, 3-9. [CrossRef]

22. Bergin, C. Promising Practices in Refugee Education; Save the Children: London, UK, 2017; Available online: https: / / resourcecentre. savethechildren.net/node/12378/pdf/promising_practices_in_refugee_education_synthesis_report_final_web.pdf (accessed on 16 July 2021).

23. Fincham, K. Rethinking higher education for Syrian refugees in Jordan, Lebanon and Turkey. Res. Comp. Int. Educ. 2020, 15, 329-356. [CrossRef]

24. Dryden-Peterson, S. Refugee Education: A Global Review; UNHCR: Geneva, Switzerland, 2011; Available online: https: / / www.unhcr.org/uk/research/evalreports/4fe317589/refugee-education-global-review-sarah-dryden-peterson-november2011.html (accessed on 16 July 2021).

25. UNICEF. The United Nations Convention on the Rights of the Child. 1989. Available online: https://www.unicef.org.uk/whatwe-do/un-convention-child-rights / (accessed on 16 July 2021).

26. Gladwell, C.; Hollow, D.; Robinson, A.; Norman, B.; Bowerman, E.; Mitchell, J.; Floremont, F.; Hutchinson, P. Higher Education for Refugees in Low-Resource Environments: Research Study; Jigsaw Consult: London, UK, 2016; Available online: https: / / connectedlearning4refugees.org/wp-content/uploads/2019/12/Jigsaw_research_study.pdf (accessed on 16 July 2021).

27. UNESCO. Reducing Global Poverty through Universal Primary and Secondary Education. 2017. Available online: http: / / unesdoc.unesco.org/images/0025/002503/250392E.pdf (accessed on 16 July 2021).

28. Wright, L.; Plasterer, W. Beyond basic education: Exploring opportunities for higher learning in Kenyan refugee camps. Refug. Can. J. Refug. 2012, 27, 42-56. [CrossRef]

29. Burde, D.; Kapit, A.; Wahl, R.L.; Guven, O.; Skarpeteig, M.I. Education in emergencies: A review of theory and research. Rev. Educ. Res. 2017, 87, 619-658. [CrossRef]

30. Miliband, D. Rescue; Simon \& Schuster: London, UK, 2017.

31. Dryden-Peterson, S. Refugee education: Education for an unknowable future. Curric. Inq. 2017, 47, 14-24. [CrossRef]

32. Crae, T.M. Refugee higher education: Contextual challenges and implications for program design, delivery and accompaniment. Int. J. Educ. Dev. 2016, 46, 12-22. [CrossRef]

33. Zeus, B. Exploring barriers to higher education in protracted refugee situations: The case of Burmese refugees in Thailand. J. Refug. Stud. 2011, 24, 256-276. [CrossRef]

34. Gladwell, C.; Hollow, D.; Robinson, A.; Norman, B.; Bowerman, E.; Mitchell, J.; Floremont, F.; Hutchinson, P. Higher Education for Refugees in Low-Resource Environments: Landscape Review; Jigsaw Consult: London, UK, 2016; Available online: https: / hubblelive-assets.s3.amazonaws.com/rsn/attachment/file/1/Landscape_review_0.pdf (accessed on 16 July 2021).

35. Dryden-Peterson, S. How Teachers can Prepare Refugees for Unknowable Futures; News Deeply: New York, NY, USA, 2017; Available online: https:/ / www.newsdeeply.com/refugees/community/2017/03/16/how-teachers-can-prepare-refugee-children-forunknowable-futures (accessed on 16 July 2021).

36. Dryden-Peterson, S.; Dahya, N.; Adelman, E. Pathways to educational success among refugees; connecting locally and globally situated resources. Am. Educ. Res. J. 2017, 54, 1011-1047. [CrossRef]

37. UNESCO. Global Education Monitoring Report 2019: Migration, Displacement and Education-Building Bridges, Not Walls. 2018. Available online: https:/ / unesdoc.unesco.org/ark:/48223/pf0000265866 (accessed on 16 July 2021).

38. European Civil Protection and Humanitarian Aid Operations (ECHO). Education in Emergencies and Protracted Crises; ECHO: Brussels, Belgium, 2018; Available online: https:/ / ec.europa.eu/echo/files/news/Communication_on_Education_in_Emergencies_ and_Protracted_Crises.pdf (accessed on 16 July 2021).

39. Global Humanitarian Assistance Report (GHA). Global Humanitarian Assistance Report. 2018. Available online: https:/ / devinit. org/resources/global-humanitarian-assistance-report-2018/ (accessed on 16 July 2021).

40. Betts, A.; Collier, P. Refuge, Transforming a Broken Refugee System; Allen Lane, Penguin Books: London, UK, 2017.

41. Human Rights Watch (HRW). The Education Deficit failures to Protect and Fulfil the Right to Education. Available online: https: / / www.hrw.org/report/2016/06/09/education-deficit/failures-protect-and-fulfill-right-education-through-global (accessed on 16 July 2021).

42. Center for Education Innovations (CEI). Topics: Education Technology. 2018. Available online: https: / /www.educationinnovations. org/b/education-technology (accessed on 16 July 2021). 
43. Stannard, L.; Tauson, M. EdTech for Learning in Emergencies and Displaced Settings; Save the Children: London, UK, 2018; Available online: https:/ / resourcecentre.savethechildren.net/node/13238/pdf/edtech-learning.pdf (accessed on 16 July 2021).

44. Brown, S.; Saint, M.; Russell, C. Education in an Extreme Environment: A University in a Refugee Camp. In Proceedings of the IEEE Global Humanitarian Technology Conference (GHTC), San Jose, CA, USA, 19-22 October 2017; IEEE: Piscataway, NJ, USA, 2017; pp. 1-10. [CrossRef]

45. Dahya, N.; Dryden-Peterson, S. Tracing Pathways to higher education for refugees: The role of virtual support networks and mobile phones for women in refugee camps. Comp. Educ. 2017, 53, 284-301. [CrossRef]

46. UNICEF. Reimagining Girls' Education. Solutions to Keep Girls Learning in Emergencies. 2021. Available online: https://www. unicef.org/media/94201/file/Reimagining\%20Girls\%20Education\%20Solutions\%20to\%20Keep\%20Girls\%20Learning\%20in\% 20Emergencies\%20.pdf (accessed on 16 July 2021).

47. Maitland, C.; Xu, Y. A Social Informatics Analysis of Refugee Mobile Phone Use: A Case Study of Za'atari Syrian Refugee Camp. In Proceedings of the TRPC 43: The 43rd Research Conference on Communication, Information and Internet; SSRN: Rochester, NY, USA, 2015; Available online: https:/ / papers.ssrn.com/sol3/papers.cfm?abstract_id=2588300\# (accessed on 16 July 2021).

48. Vodafone Foundation. Connected Education. 2017. Available online: https://www.vodafone.com/content/dam/vodcom/files/ vodafone_connected_education.pdf (accessed on 16 July 2021).

49. Strauss, A.; Corbin, J. Basics of Qualitative Research: Techniques and Procedures for Developing Grounded Theory; Sage: Thousand Oaks, CA, USA, 1998.

50. Braun, V.; Clarke, V. Using thematic analysis in psychology. Qual. Res. Psychol. 2006, 3, 77-101. [CrossRef]

51. UNESCO. Time to Roll out Education's Recovery Package. 2021. Available online: https://en.unesco.org/news/time-roll-outeducations-recovery-package (accessed on 16 July 2021).

52. Septaria, K.; Dewanti, B.A. Implementation of project based learning on student reasoning on COVID-19 disaster mitigation. Prism. Sains J. Pengkaj. Ilmu Pembelajaran Mat. IPA IKIP Mataram 2021, 9, 20-27. [CrossRef]

53. The Economist. Migrants with Mobiles. Phones are Now Indispensable for Refugees. 2017. Available online: https:/ /www.economist. $\mathrm{com} /$ international/2017/02/11/phones-are-now-indispensable-for-refugees (accessed on 16 July 2021).

54. OECD. The Impact of COVID-19 on Student Equity and Inclusion: Supporting Vulnerable Students during School Closures and School Re-Openings; OECD Policy Responses to Coronavirus (COVID-19); OECD: Paris, France, 2020. [CrossRef]

55. Hodges, T.S.; Kerch, C.; Fowler, M. Teacher education in the time of COVID-19: Creating digital networks as university-schoolfamily partnerships. Middle Grades Rev. 2020, 6, 4. Available online: https://scholarworks.uvm.edu/mgreview/vol6/iss2/4 (accessed on 16 July 2021).

56. Saboowala, R.; Manghirmalani, M.P. Readiness of in-service teachers toward a blended learning approach as a learning pedagogy in the post-COVID-19 Era. J. Educ. Technol. Syst. 2021, 50, 9-23. [CrossRef]

57. Iyengar, R. Rethinking community participation in education post Covid-19. Prospects 2021. [CrossRef]

58. Xiao, J. Decoding new normal in education for the post-COVID-19 world: Beyond the digital solution. Asian J. Distance Educ. 2021, 16, 141-155. Available online: http:/ / www.asianjde.com/ojs/index.php/AsianJDE/article/view/558 (accessed on 16 July 2021).

59. Qiao, P.; Zhu, X.; Guo, Y.; Sun, Y.; Qin, C. The development and adoption of online learning in pre- and post-COVID-19: Combination of technological system evolution theory and unified theory of acceptance and use of technology. J. Risk Financ. Manag. 2021, 14, 162. [CrossRef]

60. Crae, T.M.; McFarland, M. Higher education for refugees; lessons from a 4-year pilot study. Int. Rev. Educ. 2015, 61, 235-245. [CrossRef]

61. Ghosh, R.; Dubey, M.J.; Chatterjee, S.; Dubey, S. Impact of COVID-19 on children: Special focus on the psychosocial aspect. Minerva Pediatrica 2020, 72, 226-235. [CrossRef] [PubMed]

62. Iivari, N.; Sharma, S.; Ventä-Olkkonen, L. Digital transformation of everyday life-How COVID-19 pandemic transformed the basic education of the young generation and why information management research should care? Int. J. Inf. Manag. 2020, 55, 102183. [CrossRef] [PubMed]

63. Hamid, M.M.; Alam, T.; Rabbi, M.F.; Hasan, K.; Kuzminykh, A.; Amin, M.R. Emergence of polarization and marginalization in online education. In Design, User Experience and Usability: Design for Diversity, Well-Being, and Social Development; HCII 2021. Lecture Notes in Computer Science, 12780, Soares, M.M., Rosenzweig, E., Marcus, A., Eds.; Springer: Cham, Switzerland, 2021. [CrossRef]

64. Smith, M. Warehousing Refugees: A Denial of Rights, a Waste of Humanity. 2004. Available online: https://sswm.info/sites/ default/files/reference_attachments/SMITH\%202004\%20Warehousing\%20Refugees.pdf (accessed on 16 July 2021).

65. Wijesooriya, N.R.; Mishra, V.; Brand, P.; Rubin, B.K. COVID-19 and telehealth, education and research adaptations. Paediatr. Respir. Rev. 2020, 35, 38-42. [CrossRef] 